\title{
The effects of 4-vinylcyclohexene diepoxide on the testes of dogs
}

\author{
Zahid Paksoy ${ }^{1 *}$, Fatih M. Kandemir ${ }^{2}$, Nezihe Gokhan', \\ and Mustafa Ozkaraca ${ }^{3}$ \\ ${ }^{I}$ Veterinary Sciences, Kelkit Aydin Dogan Vocational, Gumushane University, Gumushane, Turkey \\ ${ }^{2}$ Department of Biochemistry, Veterinary Faculty, Ataturk University, Erzurum, Turkey \\ ${ }^{3}$ Department of Pathology, Veterinary Faculty, Ataturk University, Erzurum, Turkey
}

\section{PAKSOY, Z., F. M. KANDEMIR, N. GOKHAN, M. OZKARACA: The effects of 4-vinylcyclohexene diepoxide on the testes of dogs. Vet. arhiv 88, 807-822, 2018.}

\section{ABSTRACT}

This study was aimed at investigating the effects of 4-vinylcyclohexene diepoxide (VCD) on testicular tissue in dogs. For this purpose, 30 mongrel male dogs were used and allocated to 5 groups randomly. The first group $(n=6)$, used as the control, was administered sesame oil by the intraperitoneal route $(\mathrm{i} / \mathrm{p})$. The VCD was administered i/p at doses of $80,160,240,320 \mathrm{mg} / \mathrm{kg}$ to the second, third, fourth and the fifth groups $(n=6)$, respectively, once a day for 8 days. The dogs were surgically castrated on the day after the last VCD injection. The testes were removed immediately and fixed in $10 \%$ bouine solution. The testes were subjected to routine tissue processing and examined to determine the testicular damage in each testis. When compared to the control group, it was seen that the seminiferous tubule damage increased significantly in the treatment groups. Malondialdehyde levels reached the highest level in the fifth group, while superoxide dismutase, catalase, glutathione peroxidase activity and glutathione levels were higher in the control group $(\mathrm{P}<0.0001)$. Nosignificant difference was detected when all the groups were compared with respect to AST, ALT and GGT activities before and after the treatment $(\mathrm{P}>0.05)$. Our results showed that VCD may contribute to the sterilization of male dogs.

Key words: 4-vinyl cyclohexene diepoxide; chemical sterilization; dog; testis

\section{Introduction}

Nowadays, dogs are widely used in various fields. These animals are raised in cities for leisure purposes, whereas they are raised as sheep dogs in the countryside. In addition, they are used by hunters, police and military forces for different aims. However, unwanted behaviors seen in these animals overshadow their benefits. Moreover, another important problem is that dogs produce large number of puppies. Owners who have difficulties taking care of all the puppies choose to release them onto the streets. This situation

*Corresponding author:

Assist. Prof. Zahid Paksoy, Veterinary Sciences, Kelkit Aydin Dogan Vocational, Gümüshane University, 29100, Gümüshane, Turkey, E-mail: paksoyland@yahoo.com 


\section{Z. Paksoy et al.: 4-vinylcyclohexene diepoxide and testes}

increases the stray animal problem and is a threat to both human and animal health. Therefore, dog population management has become a significant subject in veterinary practice (ALAÇAM, 1999).

Various sterilization methods have been developed to reduce and control unwanted pregnancies in stray dogs. The sterilization process is carried out by hormonal, chemical and surgery methods (KUTZLER and WOOD, 2006). It has been seen that hormonal method needs sustainability and this increases the costs. Besides, when the application of hormones is interrupted, similar problems are seen again. Although surgical processes are performed successfully, post-operative complications may emerge, such as obesity, cardiac stress, enuresis, bleeding, and behavioral changes (KALKAN and ALAÇAM, 1999). Hence, the application of chemical agents with permanent effects and fewer complications has been gaining more importance in castration. (WIEBE and HOWARD, 2009; GOERICKE-PESCH, 2010; AYDIN and ABAY, 2013). Permanent castration is realized by injecting chemicals such as calcium chloride, danazol, and zinc arginine, which develop a sclerosis or toxic effect in the testicles of male animals (DIXIT, 1977; FAHIM et al., 1993; KUTZLER and WOOD, 2006; JANA and SAMANTA, 2007).

4-vinylcyclohexene diepoxide (VCD) is a metabolite of Vinyl cyclohexene (VCH). VCD is formed by epoxidation of VCH with an acidic peroxy acid. VCH is a chemical which occurs in the production of materials such as rubber, plastic, and pesticides. VCH turns into derivatives of epoxy by being metabolized in the body (IARC, 1994; DHILLON and VON, 1996; BHATTACHARYA and KEATING, 2011; VAN KEMPEN et al., 2011). VCH itself and its metabolites show a toxic effect on the ovaries and causes atrophy in the follicles. In a recent study, VCD application resulted in increased oxidative stress in the liver and kidneys. It also increased the amount of interleukin 1 beta, which causes inflammation in the body. In general, VCD is stronger than $\mathrm{VCH}$ and for this reason it may be used in smaller doses (HOYER and MAYER, 2009; ABOLAJI et al., 2016a). There is no available clinical study regarding the effects of the VCD on the testicles of dogs. We hypothesized that the VCD treatment would destroy germ cells in the testicles of dogs. Furthermore, we discussed oxidative stress caused by the VCD on testicles and liver.

\section{Materials and methods}

Material. The subjects of the study were 30 dogs at the ages of 1 to 2 ; and between the weights of 10 to $25 \mathrm{~kg}$. An andrological examination of dogs was performed and it was determined that they were healthy. The VCD (purity $>96 \%$ ) was bought from Sigma Aldrich, and the sesame oil was purchased from Acros Organics. Before initiating the study, permission was obtained from the Gumushane University, Animal Experiments Local Ethical Board (dated 01.03.2012, and approval number 2012-02). 
Methods. The dogs were randomly separated into 5 groups. Each group consisted of 6 dogs. First of all, blood was taken from the dogs and serum samples were obtained and stored at $-20{ }^{\circ} \mathrm{C}$ in a deep freezer. The animals in the first group $(n=6)$ were used as controls and $2 \mathrm{~mL}$ of sesame oil was given daily for 8 days by the intraperitoneal (i.p.) route. Sesame oil $+\mathrm{VCD}$ was administered via $\mathrm{i} / \mathrm{p}$ to the animals in the treatment groups: daily doses of $80 \mathrm{mg} / \mathrm{kg}$ VCD for the dogs in the second group $(\mathrm{n}=6), 160$ $\mathrm{mg} / \mathrm{kg}$ to the third group $(\mathrm{n}=6), 240 \mathrm{mg} / \mathrm{kg}$ to the fourth group $(\mathrm{n}=6)$, and $320 \mathrm{mg} /$ $\mathrm{kg}$ to the fifth group, were administered for 8 days via $\mathrm{i} / \mathrm{p}$ application. Previous studies were considered to determine the route and time of administration of the VCD dose in animals (DEVINE et al., 2001; HOOSER et al., 1995; MAYER et al., 2002; MAYER et al., 2004; SAHAMBI et al., 2008). The VCD was given to the animals under sedation through a median line. Blood was taken from the animals and serum was obtained one day after the last injection, and stored at $-20^{\circ} \mathrm{C}$. Furthermore, the castration surgery was also performed after the last VCD application, and the testicles were removed. One of the testicles was placed into a $10 \%$ bouine solution for histopathological research, and the other one was kept at $-80{ }^{\circ} \mathrm{C}$ for biochemical analysis.

Histopathological analysis. The testes were removed immediately, fixed in $10 \%$ bouine solution for 24-48 hours, and then processed to obtain paraffin blocks. Paraffinembedded blocks were routinely processed: $5-\mu \mathrm{m}$ thick sections were stained with hematoxylin-eosin and examined under a microscope, and 10 randomly selected tubules were examined under $20 \times$ magnification. They were assessed histopathologically using Johnsen's mean testicular biopsy score (MTBS) criteria (JOHNSEN, 1970). A score of 0-10 was given to each tubule according to epithelial maturation.

Immunohistochemical analysis. After deparaffinization, the slides were immersed in antigen retrieval solution $(\mathrm{pH} \mathrm{6.0)}$ ) and heated in a microwave for 15 minutes to unmask the antigens. The sections were then dipped in $3 \% \mathrm{H}_{2} \mathrm{O}_{2}$ for 10 minutes to block the endogenous peroxidase. The sections were incubated at room temperature with polyclonal rabbit 8-OhDG antibody (cat. no. ab62623, dilution 1/200; Abcam, UK). An expose mouse and rabbit specific HRP/DAB detection IHC kit was used as follows: the sections were incubated with goat anti-mouse antibody, then with streptavidin peroxidase, and finally with $3,3^{\prime}$ diaminobenzidine + chromogen. Slides were counterstained with hematoxylin. Then 10 randomly selected tubules were examined under $20 \times$ magnifications. Immunoreactivity in the sections was graded as 0 (none), 1 (mild), 2 (moderate), 3 (severe) and 4 (very severe).

Biochemical analysis. Isolated testicular tissues were homogenized in a homogenizer using a buffer of $1.15 \% \mathrm{KCl}$ to obtain a $1: 10(\mathrm{w} / \mathrm{v})$ homogenate. According to the method of PLACER et al. (1966), the malondialdehyde (MDA) levels in the testes homogenate were measured using thiobarbituric acid reactive substances. The MDA formed created a pink complex with thiobarbituric acid and the absorbance was measured at $532 \mathrm{~nm}$ wavelength. The MDA levels of testicular tissue were expressed as nmol/g tissue. Testicular tissue glutathione (GSH) levels were measured by color change at $412 \mathrm{~nm}$, 
according to the method of SEDLAK and LINDSAY (1968) and expressed as nmol/g of the testicular tissue. Testes catalase (CAT) activity was measured according to the method of AEBI (1987). The decomposition rate of $\mathrm{H}_{2} \mathrm{O}_{2}$ by the CAT was spectrophotometrically measured as the amount of change in $\mathrm{H}_{2} \mathrm{O}_{2}$ light absorption at $240 \mathrm{~nm}$ wavelength, and was expressed as katal/g of protein. Superoxide dismutase (SOD) activity was measured according to the method of SUN et al. (1988). The SOD enzyme activity measurement was based on the nitroblue tetrazolium (NBT) degradation by the superoxide radical, which was produced with the xanthine-xanthine oxidase system and formazan; its creation was measured at $560 \mathrm{~nm}$ wavelength and was expressed as $\mathrm{U} / \mathrm{g}$ protein. The glutathione peroxidase (GPx) activity in the testicular tissue was measured according to the method of LAWRENCE and BURK (1976) and was expressed as U/g of protein. Protein concentration was measured according to the method of LOWRY et al. (1951).

The alanine aminotransferase (ALT), aspartate aminotransferase (AST) and gamma glutamyl transferase (GGT) activities were measured using an automatic biochemistry analyzer (BS-120, Mindray, China).

Statistical analysis. All statistical analyses were carried out using Graphpad Prism (GraphPad Software, version 6.0). All data were presented as mean ( \pm ) standard error mean (S.E.M.). The differences in the measured parameters between the five groups were analyzed with a nonparametric test (Kruskal-Wallis). Dual comparisons between the groups exhibiting significant values were evaluated with a Mann-Whitney U-test $(\mathrm{P}<0.05)$. The AST, ALT, and GGT values of pre-treatment and post-treatment were compared by means of the Wilcoxon test.

\section{Results}

Histopathologic findings. It was observed that seminiferous tubules in the control group had normal structure (Fig 1a). Depending on the increase in the dose, deterioration was observed in the structure of spermatogenic cells in the testicles of the animals among the VCD treated animals in the $2^{\text {nd }}, 3^{\text {rd }}, 4^{\text {th }}$, and $5^{\text {th }}$ groups and an increase in the necrotic and degenerative changes in the seminiferous tubules through shedding (Figs 1b, 1c, 1d, 1e, Table 1).

Table 1. Histopathological and immunohistochemical comparison of the groups in terms of damage to the testicles

\begin{tabular}{|l|c|c|}
\hline Groups & Histopathological Mean \pm SEM & Immunohistochemical Mean \pm SEM \\
\hline I & $9.16 \pm 0.30^{\mathrm{a}}$ & $0.33 \pm 0.21^{\mathrm{a}}$ \\
\hline II & $6.63 \pm 0.21^{\mathrm{b}}$ & $2.16 \pm 0.16^{\mathrm{b}}$ \\
\hline III & $5.16 \pm 0.16^{\mathrm{c}}$ & $2.33 \pm 0.21^{\mathrm{b}}$ \\
\hline IV & $3.33 \pm 0.21^{\mathrm{d}}$ & $3.16 \pm 0.16^{\mathrm{c}}$ \\
\hline V & $1.66 \pm 0.21^{\mathrm{e}}$ & $3.66 \pm 0.21^{\mathrm{d}}$ \\
\hline
\end{tabular}

${ }_{a, b, c, d, e} \mathrm{P}<0.05$ versus other groups. 

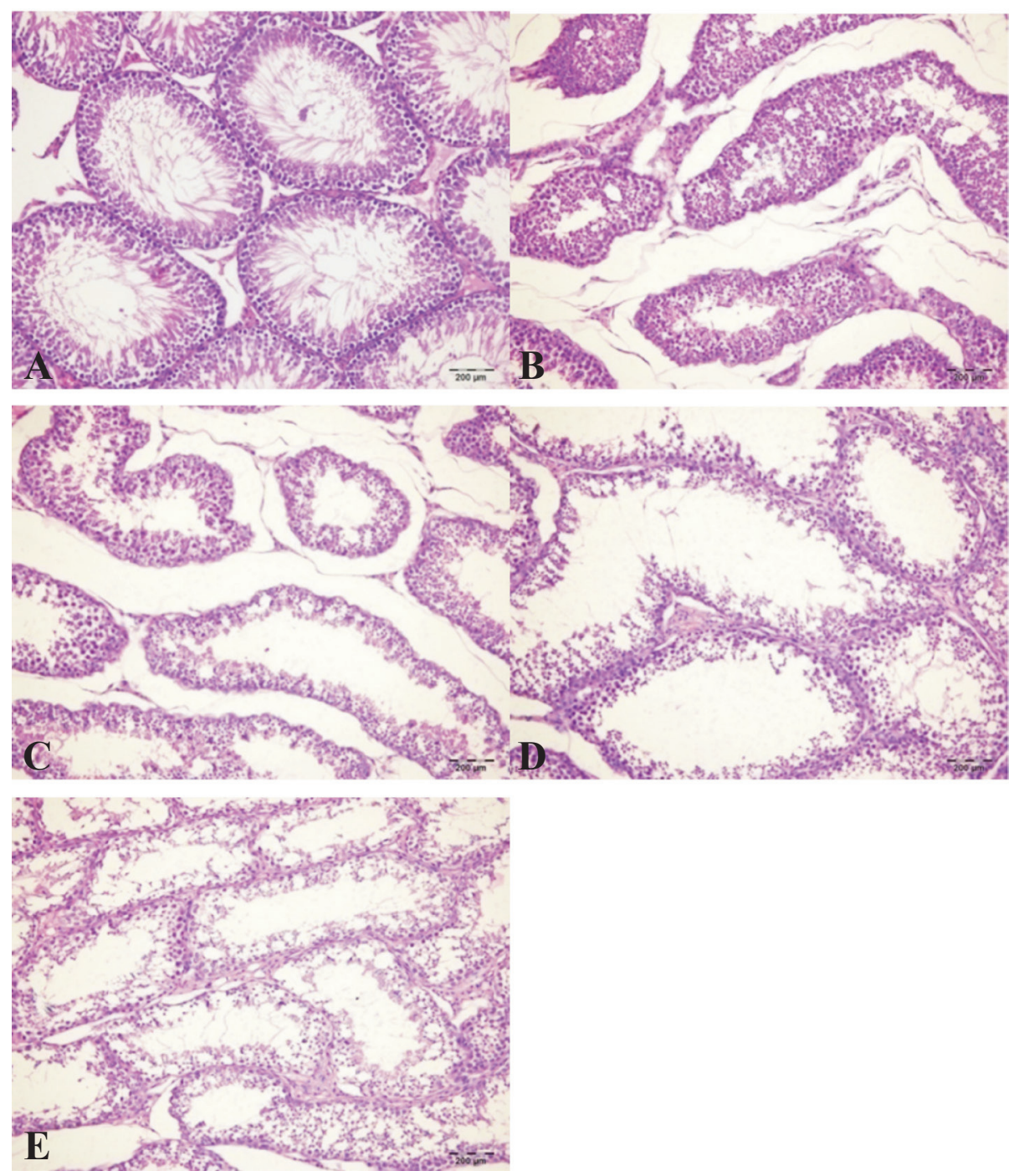

Fig. 1. Photomicrographics of the testicles of the animals in the control and treatment groups.

A) Seminiferous tubules with normal structure belong to the animals in the control group.

B) Mild necrotic and degenerative changes in the seminiferous tubules of animals in the second group.

C) Moderate necrotic and degenerative changes in the seminiferous tubules in the third group.

D) Severe necrotic and degenerative changes in the seminiferous tubules in the fourth group.

E) Very severe necrotic and degenerative changes in the seminiferous tubules in the fifth group. 

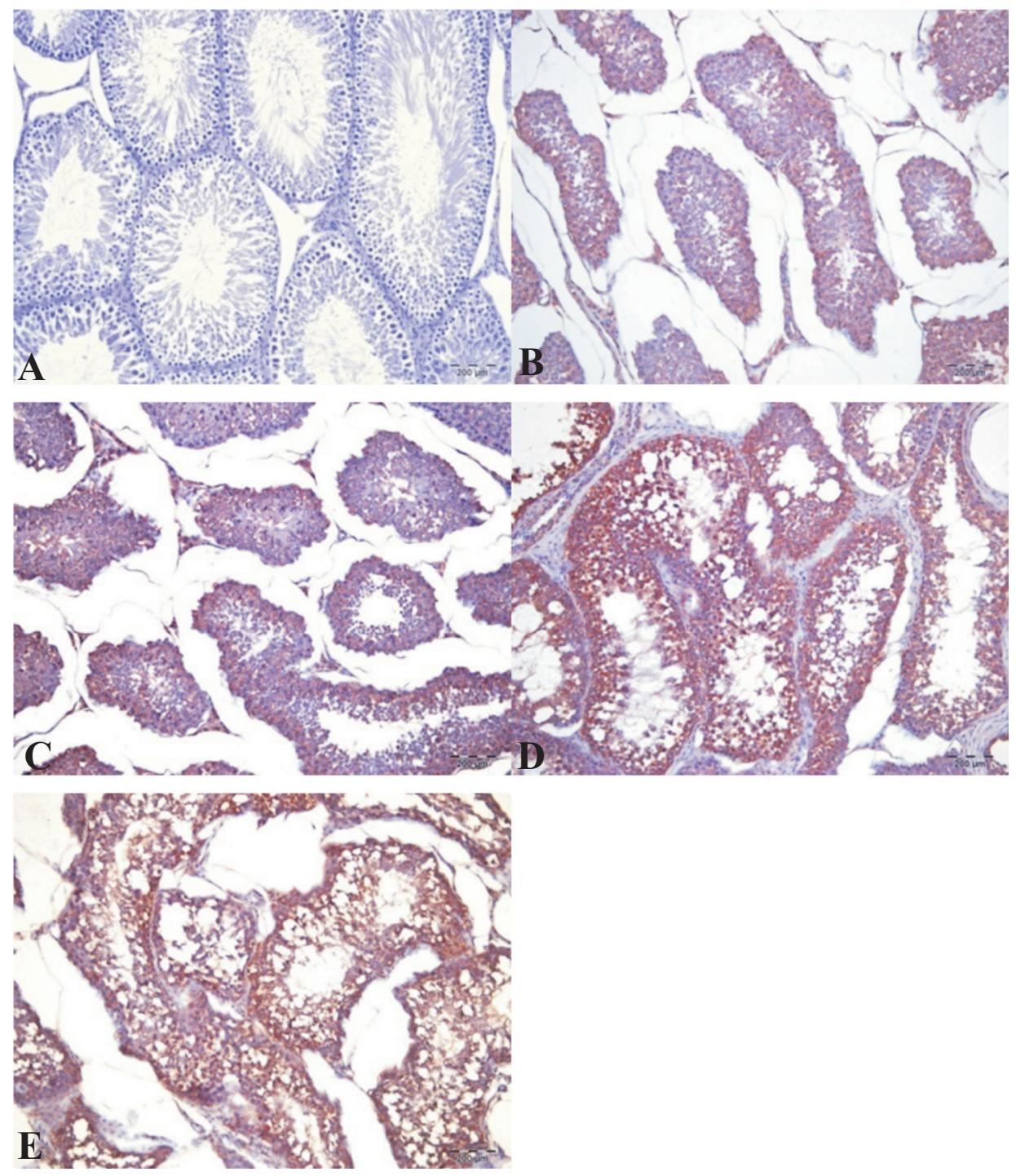

Fig. 2. Immunohistochemical staining indicating $8-\mathrm{OhDG}$ expressions in the testes of dogs. A) Negativity of the $8-\mathrm{OhDG}$ in the control group. B) In the $2^{\text {nd }}$ group; moderate expression of 8 -OhDG in the seminiferous tubules. C) In the $3^{\text {rd }}$ group: moderate expression of 8 -OhDG in the seminiferous tubules. D) In the $4^{\text {th }}$ group: severe expression of $8-\mathrm{OhDG}$ in the seminiferous tubules. E) In the $5^{\text {th }}$ group: very severe expression of $8-\mathrm{OhDG}$ in the seminiferous tubules. 
Immunohistochemical findings. The expression of $8-\mathrm{OhDG}$, used as a marker to determine DNA destruction, slightly increased in the two samples in the control group (Figure 2a). Expression of the 8-OhDG was observed as moderate in the $2^{\text {nd }}$ and $3^{\text {rd }}$ group, as severe in the $4^{\text {th }}$ group, and as very severe in the $5^{\text {th }}$ group (Figs $2 \mathrm{~b}, 2 \mathrm{c}, 2 \mathrm{~d}, 2 \mathrm{e}$, Table 1), respectively.

Biochemical findings. The MDA levels of testicle homogenates were compared and it was observed that the differences between the groups were significant $(\mathrm{P}<0.0001)$. Then, when the control group and the treatment groups were compared dually, it was identified that MDA levels in the $2^{\text {nd }}$ group $(\mathrm{P}<0.05), 3^{\text {rd }}, 4^{\text {th }}$, and $5^{\text {th }}$ groups $(\mathrm{P}<0.01)$ increased significantly, and the greatest increase occurred in the $5^{\text {th }}$ group (Fig. 3 ).

\section{MDA}

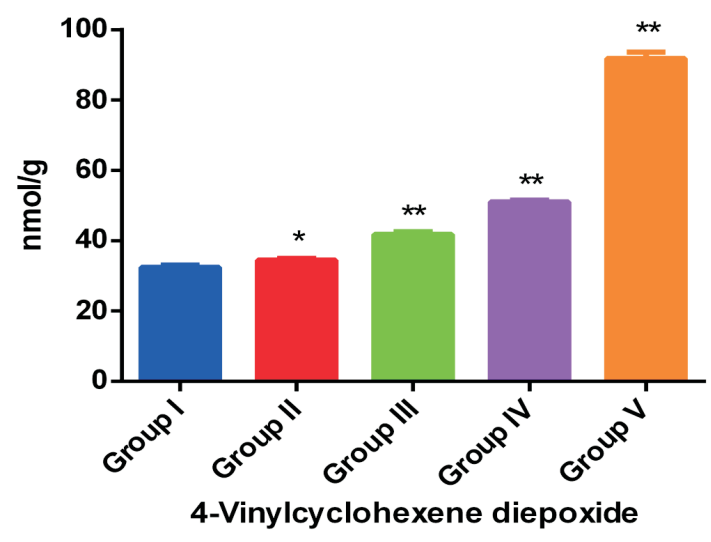

Fig. 3. Comparison of the MDA levels (nmol/g) following VCD administration according to the groups (Each bar expresses mean $\pm \mathrm{SEM} .{ }^{*} \mathrm{P}<0.05,{ }^{* *} \mathrm{P}<0.01$ versus control

When the SOD, CAT, GSH, and GPX levels in the testicular tissues are compared between the groups, it was seen that the differences were very significant $(\mathrm{P}<0.0001)$. After that, the control group and the treatment groups were compared dually. The SOD, CAT, GSH, and GPx levels of the dogs in the control group were found to be very significant when compared to the treatment groups ( $\mathrm{P}<0.01$ ), (Figs 4, 5, 6, 7). 


\section{SOD}

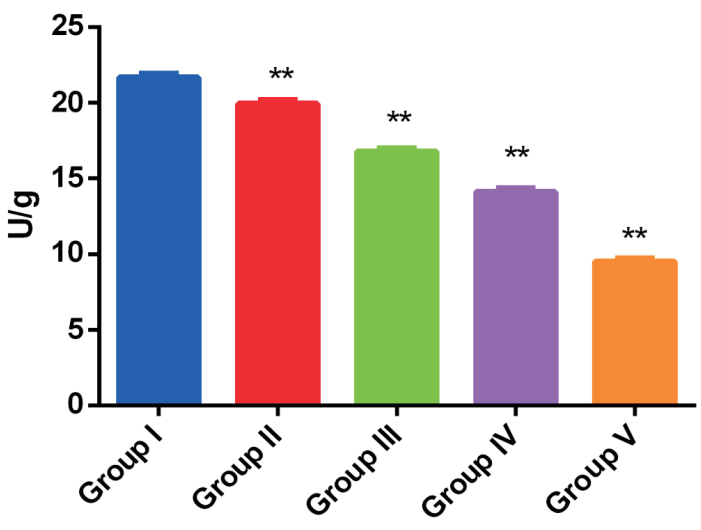

4-Vinylcyclohexene diepoxide

Fig. 4. SOD levels (U/g) of the dogs following VCD treatment (Each bar expresses mean $\pm \mathrm{SEM}$. $* * \mathrm{P}<0.01$ versus control)

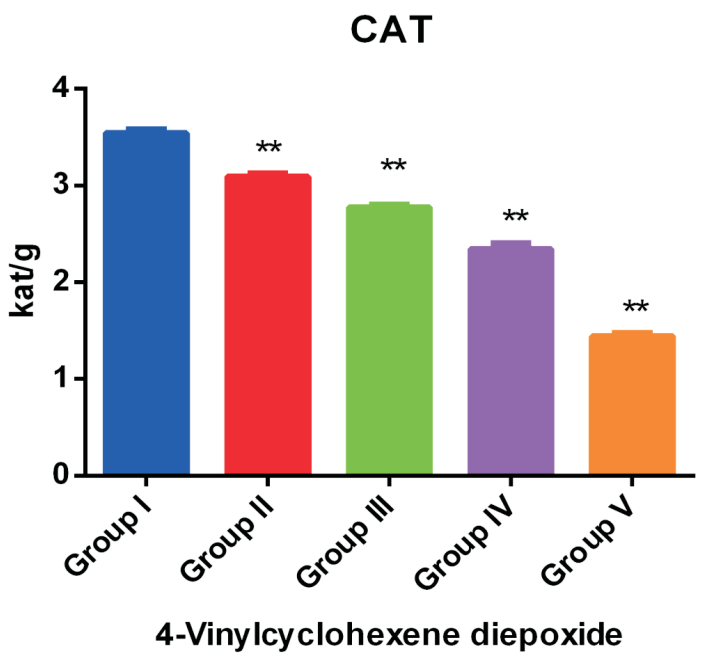

Fig. 5. CAT levels (katal/g) of the dogs following VCD treatment (Each bar expresses mean \pm SEM. $* * \mathrm{P}<0.01$ versus control) 


\section{GSH}

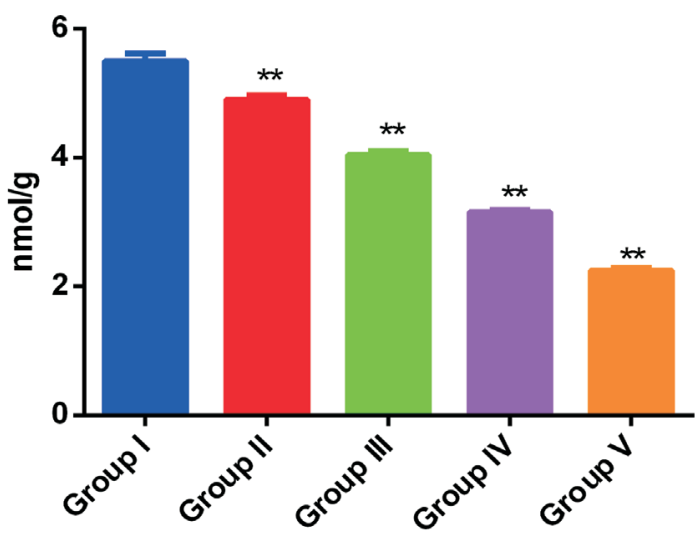

4-Vinylcyclohexene diepoxide

Fig. 6. GSH levels (nmol/g) of the dogs following VCD treatment (Each bar expresses mean \pm SEM. $* * \mathrm{P}<0.01$ versus control)

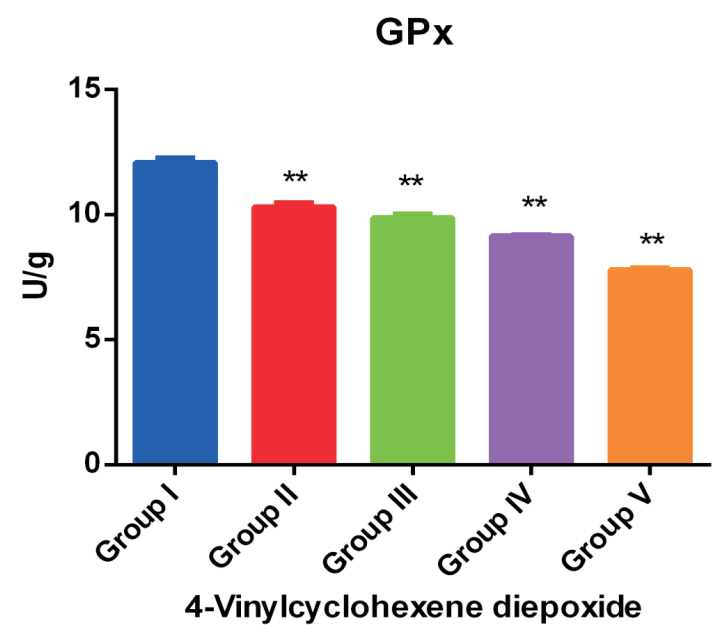

Fig. 7. GPx levels $(\mathrm{U} / \mathrm{g})$ of the dogs following VCD treatment (Each bar expresses mean $\pm \mathrm{SEM}$. $* * \mathrm{P}<0.01$ versus control)

ALT, AST, and GGT enzyme levels in the blood serum were compared having been collected pre- and post-treatment. The first and second blood samples taken from the 
same animals were compared using the Wilcoxon test. When the pre-and post-treatment values in the all groups were compared, no significant difference was identified in the levels of ALT, AST, and GGT (P>0.05) (Table 2).

Table 2. Values of the AST, ALT and GGT enzymes pre-and post VCD administration according to the groups

\begin{tabular}{|c|c|c|c|c|c|c|c|c|}
\hline Groups & $\mathrm{N}$ & Pre-AST & Post-AST & Pre-ALT & Post-ALT & Pre-GGT & Post- GGT & $\mathrm{P}$ \\
\hline I & 6 & $\begin{array}{c}27.50 \\
\pm 1.47\end{array}$ & $\begin{array}{c}37.33 \\
\pm 4.44\end{array}$ & $\begin{array}{c}33.83 \\
\pm 2.02\end{array}$ & $\begin{array}{c}31.33 \\
\pm 4.20\end{array}$ & $\begin{array}{c}3.66 \\
\pm 0.33\end{array}$ & $\begin{array}{c}2.83 \\
\pm 0.40\end{array}$ & - \\
\hline II & 6 & $\begin{array}{l}41.17 \\
\pm 0.94\end{array}$ & $\begin{array}{c}45.33 \\
\pm 3.08\end{array}$ & $\begin{array}{r}41.00 \\
\pm 3.39\end{array}$ & $\begin{array}{r}46.67 \\
\pm 5.11 \\
\end{array}$ & $\begin{array}{c}4.00 \\
\pm 0.44\end{array}$ & $\begin{array}{c}4.66 \\
\pm 0.49\end{array}$ & - \\
\hline III & 6 & $\begin{array}{r}47.00 \\
\pm 1.12 \\
\end{array}$ & $\begin{array}{c}53.33 \\
\pm 1.76 \\
\end{array}$ & $\begin{array}{c}30.83 \\
\pm 3.30 \\
\end{array}$ & $\begin{array}{r}31.83 \\
\pm 3.61 \\
\end{array}$ & $\begin{array}{c}3.16 \\
\pm 0.30 \\
\end{array}$ & $\begin{array}{c}3.00 \\
\pm 0.36 \\
\end{array}$ & - \\
\hline IV & 6 & $\begin{array}{c}30.33 \\
\pm 1.20 \\
\end{array}$ & $\begin{array}{c}31.83 \\
\pm 0.83 \\
\end{array}$ & $\begin{array}{r}24.00 \\
\pm 1.15 \\
\end{array}$ & $\begin{array}{c}24.33 \\
\pm 1.28 \\
\end{array}$ & $\begin{array}{c}4.00 \\
\pm 0.51 \\
\end{array}$ & $\begin{array}{c}4.66 \\
\pm 0.21 \\
\end{array}$ & - \\
\hline V & 6 & $\begin{array}{c}36.00 \\
\pm 4.13\end{array}$ & $\begin{array}{c}32.50 \\
\pm 0.95\end{array}$ & $\begin{array}{c}34.00 \\
\pm 1.77\end{array}$ & $\begin{array}{c}36.67 \\
\pm 1.66\end{array}$ & $\begin{array}{c}3.16 \\
\pm 0.54\end{array}$ & $\begin{array}{c}3.66 \\
\pm 0.55\end{array}$ & - \\
\hline
\end{tabular}

- : $\mathrm{P}>0.05$; results were expressed as mean \pm SEM

\section{Discussion}

The aim of this study was to evaluate the effects of VCD treatment on dog testes. VCD was used for the first time in male dogs in this study. Our findings show that reproduction can be controlled by VCD treatment.

Nowadays, the most common way to prevent unwanted mating in male dogs is surgical castration. However, very serious complications may occur after this operation, and even death. Moreover, not all animal owners can afford this operation because of the high cost. As a result of this situation, studies of non-surgical sterilization methods are being increasingly conducted (KALKAN and ALAÇAM, 1999; ALAÇAM, 1999; SALHAB et al., 1999; FAIL et al., 2000; EILTS, 2002; YODER and MILLER, 2010). Among these methods, chemical castration is gaining importance. At this point, VCD is a well-known agent (KAO et al., 1999; MAYER et al., 2002; KODAMA et al., 2009). Recent studies have focused on the effects of VCD on ovarian follicles (ABOLAJI et al. 2016b). Within the literature review, two studies were found about usage of VCD in female dogs. In one of these studies (MIERS et al., 2005), the researchers administered 80,160 , or $240 \mathrm{mg} / \mathrm{kg}$ of VCD to puppies for 6 days, and after 30 days they performed ovariohysterectomy. They found that all the doses of VCD in puppies caused a significant decrease in the number of primordial follicles. In the other study (PAKSOY, 2012), VCE, which is another metabolite of the $\mathrm{VCH}$, was applied once in a dose of $160 \mathrm{mg} / \mathrm{kg}$. After this administration, it was identified that there was a significant decrease in the number of 


\section{Z. Paksoy et al.: 4-vinylcyclohexene diepoxide and testes}

primordial and primary follicles. This situation shows that the metabolites of $\mathrm{VCH}$ also have ovotoxic effect in the dogs. In this study, sperm count decreased dramatically with the 80 and $160 \mathrm{mg} / \mathrm{kg}$ dose, remarkable degeneration formed in the seminiferous tubules with the $240 \mathrm{mg} / \mathrm{kg}$ dose, and necrotic changes were observed with the administration of a $320 \mathrm{mg} / \mathrm{kg}$ dose of VCD. These outcomes are indicators of oxidative damage caused by the VCD in the testicles. The gonad tissue in the males was specifically affected just as in the females.

The MDA is a product which arises from lipid peroxidation and an indicator of oxidative stress (DEL RIO et al., 2005). In this study, testicular MDA levels increased remarkably after the VCD injection. Oxidative stress increased and degeneration might have occurred as a result of this increase in the seminiferous tubules. Anti-oxidant enzymes such as SOD, CAT, GSH and GPx protect the tissues by means of different mechanisms and prevent the occurrence of damage (MATES, 2000). In the present study, the level of these enzymes in the male dogs given VCD decreased significantly compared to the control group. This decrease became more severe, especially with higher doses of VCD treatment. This situation may be one of the causes of testicular damage. On the one hand the MDA amount increased, on the other hand anti-oxidant enzyme levels decreased; and as a result of this imbalance, oxidative stress may occur. This situation might be the reason for the damage in the testicles. Giving an anti-oxidant agent, such as sesame oil, to dogs might be another reason for this difference in the control group (AHMAD et al., 2006).

ALT and AST are enzymes which are abundant in the liver. They are found in low amounts in the blood under normal conditions. They pass into the blood in large amounts when liver damage occurs. These enzymes are used in liver function tests for this reason (HUANG et al., 2006). The GGT enzyme is found in the whole body, but it is especially localized in the kidneys and livers. This enzyme, which is found in the plasma membrane, helps GSH synthesis and contributes to the anti-oxidant defense mechanism. At the same time, it is used widely in the diagnosis of liver diseases as a marker (LEE et al., 2004). In a study conducted on rats (ABOLAJI et al., 2016a), VCD was administered to animals orally for 28 days, in 3 different doses $(100,250$, or $500 \mathrm{mg} / \mathrm{kg} / \mathrm{day})$. At the end of the study, the AST levels in the male rats treated with a dose of $250 \mathrm{mg}$ increased significantly, as did the ALT levels in those treated with doses of 100 and $500 \mathrm{mg}$, and the GGT levels in those receiving 250 and $500 \mathrm{mg}$ doses of VCD. Contrary to this study, there was no significant difference between the control group and the treatment groups in our study. This situation, ABOLAJI et al. (2016a) might have been caused by the long term VCD administration. Due to the oral administration, the VCD was absorbed by the intestines and transfused to the blood stream through the liver. This transfusion might have caused a change in the liver enzyme levels. 
There are a few studies which have tested the effects of VCD on the testicles (CHHABRA et al., 1990; HOOSER et al., 1995; ADEDARA et al., 2017). In a study carried out by HOOSER et al. (1995), they examined the effects of VCD on the testicles of male mice. The researchers administered a $320 \mathrm{mg} / \mathrm{kg}$ dose of VCD to mice for 5 , $10,15,20,25$, and 30 days. Especially after the $20^{\text {th }}$ day, they reported intense germ cell loss. In a study conducted on rats and mice by CHHABRA et al, (1990), VCD was administered by the dermal and oral routes for 13 weeks. It was reported that damage in the testicles and ovaries occurred in the mice which received VCD orally, but this injury did not take place in the rats. In another study by ADEDARA et al. (2017), it was reported that toxic effects and inflammation were seen with VCD administration. They also stated that caspase-3 and caspase-9 expression increased in the immunohistochemical analysis which might cause apoptosis. In the present study, testicular damage was seen in all the dogs that were given VCD. The greatest loss took place especially in the group given $320 \mathrm{mg} / \mathrm{kg} \mathrm{VCD}$. In the immunohistochemical analysis conducted, while 8-OhDG was expressed mildly in the control group, it was expressed at a moderate level in the $2^{\text {nd }}$ and $3^{\text {rd }}$ groups, a severe level in the $4^{\text {th }}$ group, and very severe in the $5^{\text {th }}$ group. The expression of this gene indicates the oxidative damage and stress in the testicle. Our results are in accordance with the studies mentioned above and the VCD caused toxic effects on the germ cells in testes of the dogs.

As a result, this study identified that VCD causes germ cell damage, depending on the dose, in the seminiferous tubules in male dogs. The occurrence of no negative effects on the liver enzymes shows that VCD specifically affects the gonadal tissue. When these results were considered, it was concluded that VCD may contribute to the chemical sterilization of male dogs. Furthermore, the effects of this chemical on other organs and tissues should be studied in further studies in more detail.

\section{Acknowledgements}

This study has been supported by Gümüşhane University Scientific Research Projects Coordination Department. Project Number: 14.B0121.02.02

This study was presented as poster at the $3^{\text {rd }}$ International Vetistanbul Group Congress.

\section{References}

ABOLAJI, A. O., P. E. TOLOYAI, T. D. ODELEYE, S. AKINDURO, J. B. TEIXEIRA ROCHA, E. O. FAROMBI (2016a): Hepatic and renal toxicological evaluations of an industrial ovotoxic chemical, 4-vinylcyclohexene diepoxide, in both sexes of Wistar rats. Environ. Toxicol. Pharmacol. 45, 28-40.

DOI: $10.1016 /$ j.etap.2016.05.010 
ABOlAJI, A. O., I. A. ADEDARA, A. O. ABAJINGIN, O. J. FATUNMIBI, E. O. LADIPO, E. O. FAROMBI (2016b): Evidence of oxidative damage and reproductive dysfunction accompanying 4-vinylcyclohexene diepoxide exposure in female Wistar rats. Reprod. Toxicol. $66,10-19$.

DOI: 10.1016/j.reprotox.2016.09.009

ADEDARA, I. A., A. O. ABOLAJI, E. O. LADIPO, O. J. FATUNMIBI, A. O. ABAJINGIN, E. O. FAROMBI (2017): 4-Vinylcyclohexene diepoxide disrupts sperm characteristics, endocrine balance and redox status in testes and epididymis of rats. Redox Rep. 22, 388-398.

DOI:10.1080/13510002.2016.1259718

AEBI, H. (1987): Catalase. In: Methods of Enzymatic Analysis, $3^{\text {rd }}$ ed., (Bergmeyer, H. U., Ed.). Verlag Chemie, Weinheim, pp. 273-286.

AHMAD, S., S. YOUSUF, T. ISHRAT, M. B. KHAN, K. BHATIA, I. S. FAZLI, J. S. KHAN, N. H. ANSARI, F. ISLAM (2006): Effect of dietary sesame oil as antioxidant on brain hippocampus of rat in focal cerebral ischemia. Life Sci. 79, 1921-1928.

DOI: $10.1016 /$ j.lfs.2006.06.017

ALAÇAM, E. (1999): Management of reproduction. In: Birth and Infertility in Domestic Animals (Alaçam, E., Ed.), 2 ${ }^{\text {nd }}$ ed., Medisan Yayınevi, Ankara, pp. 43-56 (in Turkish).

AYDIN, I., M. ABAY (2013): Management of reproduction. In: Obstetrics and Gynecology in Cats and Dogs. (Kaymaz, M., M. Fındık, A. Rişvanlı, A. Köker, Eds.), Medipres Matbaacılık Ltd. Şti, Malatya, pp. 317-343 (in Turkish).

BHATTACHARYA, P., A. F. KEATING (2011): Ovarian metabolism of xenobiotics. Exp. Biol. Med. 236, 765-771.

DOI: $10.1258 / \mathrm{ebm} .2011 .011051$

CHHABRA, R. S., M. R. ELWELL, A. PETERS (1990): Toxicity of 4-vinyl-1-cyclohexene diepoxide after 13 weeks of dermal or oral exposure in rats and mice. Fundam. Appl. Toxicol. $14,745-751$.

DOI: $10.1093 /$ toxsci/14.4.745

DEL RIO, D., A. J. STEWART, N. PELLEGRINI (2005): A review of recent studies on malondialdehyde as toxic molecule and biological marker of oxidative stress. Nutr. Metab. Cardiovasc. Dis. 15, 316-28.

DOI: 10.1016/j.numecd.2005.05.003

DEVINE, P. J., I. G. SIPES, P. B. HOYER (2001): Effect of 4-vinylcyclohexene diepoxide dosing in rats on GSH levels in liver and ovaries. Toxicol. Sci. 62, 315-320.

DOI: $10.1093 /$ toxsci/62.2.315

DHILLON, S., R. B. VON (1996): Vinylcyclohexene dioxide. J. Appl. Toxicol. 16, 465-468. DOI: $10.1002 /$ jat.2550160503

DIXIT, V. P. (1977): Chemical sterilization: effects of danazol administration on the testes and epididymides of male rabbit. Acta Biol. Med. Ger. 36, 73-78. 
EILTS, B. E. (2002): Pregnancy termination in the bitch and queen. Clin. Tech. Small. Anim. Pract. $17,116-123$.

DOI: $10.1053 /$ svms.2002.34325

FAHIM, M. S., M. WANG, M. F. SUTCU, Z. FAHIM, R. S. YOUNGQUIST (1993): Sterilization of dogs with intra-epididymal injection of zinc arginine. Contraception 47, 107-122.

DOI: 10.1016/0010-7824(93)90113-L

FAIL, P. A., P. MARTIN, D. SOKAL (2000): Comparative effects of quinacrine and erythromycin in adult female rats: a nonsurgical sterilization study. Fertil. Steril. 73, 387-394.

DOI: 10.1016/S0015-0282(99)00537-3

GOERICKE-PESCH, S (2010): Reproduction control in cats, new developments in non-surgical methods. J. Feline. Med. Surg. 12, 539-546.

DOI: $10.1016 /$ j.jfms.2010.05.005

HOOSER, S. B., D. G. DEMERELL, D. A. DOUDS, P. HOYER, I. G. SIPES (1995): Testicular germ cell toxicity caused by vinylcyclohexene diepoxide in mice. Reprod. Toxicol. 9, 59-67.

DOI: 10.1016/0890-6238(95)00022-3

HOYER, P. B., L. P. MAYER (2009): Animal model for perimenopause and menopause and methods of inducing ovarian failure. US Patent.

HUANG, X. J., Y. K. CHOI, H. S. IM, O. YARIMAGA, E. YOON, H. S. KIM (2006): Aspartate aminotransferase (AST/GOT) and alanine aminotransferase (ALT/GPT) detection techniques. Sensors 6, 756-782.

DOI: $10.3390 / \mathrm{s} 6070756$

IARC (1994): Some Industrial Chemicals. IARC Monographs on the Evaluation of Carcinogenic Risks to Humans, 60, Lyon, France,

JOHNSEN, S. G. (1970): Testicular biopsy score count - a method for registration of spermatogenesis in human testes. Normal values and results of 335 hypogonadal males. Hormones 1, 2-25.

DOI: $10.1159 / 000178170$

JANA, K., P. K. SAMANTA. (2007): Sterilization of male stray dogs with a single intratesticular injection of calcium chloride: a dose-dependent study. Contraception 75, 390-400.

DOI: $10.1016 /$ j.contraception.2007.01.022

KALKAN, C., E. ALAÇAM (1999): Gynecological operations. In: Birth and Infertility in Domestic Animals (Alaçam, E., Ed.), $2^{\text {nd }}$ ed., Medisan Yayınevi, Ankara, pp. 383-400 (in Turkish).

KAO, S. W., I. G. SIPES, P. B. HOYER (1999): Early effects of ovotoxicity induced by 4-vinylcyclohexene diepoxide in rats and mice. Reprod. Toxicol. 13, 67-75.

DOI: 10.1016/S0890-6238(98)00061-6

KODAMA, T., J. YOSHIDA, T. MIWA, D. HASEGAWA, T. MASUYAMA (2009): Collaborative work on evaluation of ovarian toxicity. 4) Effects of fertility study of 4-vinylcyclohexene diepoxide in female rats. J. Toxicol. Sci. 34, SP 59-63.

DOI: $10.2131 /$ jts.34.S59 
KUTZLER, M., A. WOOD (2006): Non-surgical methods of contraception and sterilization. Theriogenology 66, 514-25.

DOI: 10.1016/j.theriogenology.2006.04.014

LAWRENCE, R. A., R. F. BURK (1976): Glutathione peroxidase activity in selenium deficient rat liver. Bioch. Biophys. Res. Comm. 71, 952-958.

DOI: 10.1016/0006-291X(76)90747-6

LEE, D. H., R. BLOMHOFF, D. R. JACOBS (2004): Is Serum Gamma Glutamyltransferase a Marker of Oxidative Stress? Free Radic. Res. 38, 535-539.

DOI: $10.1080 / 10715760410001694026$

LOWRY, O. H., N. J. ROSEBROUGH, A. L. FARR, R. J. RANDALL (1951): Protein measurement with the folin phenol reagent. J. Biol. Chem. 193, 265-275.

MATÉS, J. M. (2000): Effects of antioxidant enzymes in the molecular control of reactive oxygen species toxicology. Toxicology 153, 83-104.

DOI: $10.1016 / \mathrm{S} 0300-483 \mathrm{X}(00) 00306-1$

MAYER, L. P., N. A. PEARSALL, P. J. CHRISTIAN, P. J. DEVINE, C. M. PAYNE, M. K. MCCUSKEY, S. L. MARION, I. G. SIPES, P. B. HOYER (2002): Long-term effects of ovarian follicular depletion in rats by 4-vinylcyclohexene diepoxide. Reprod. Toxicol. 16, 775-781.

DOI: 10.1016/S0890-6238(02)00048-5

MAYER, L. P., P. J. DEVINE, C. A. DYER, P. B. HOYER (2004): The follicle-deplete mouse ovary produces androgen. Biol. Reprod. 71, 130-138.

DOI: 10.1095/biolreprod.103.016113

MIERS, H. J., C. A. DYER, R. B. CRAIG, D. KALLECO, K. R. KARR, Z. D. ROBINSON, S. L. MARION, P. B. HOYER, B. J. BALOK, L. P. MAYER (2005): 4-vinylcyclohexene diepoxide-induced-primordial follicle depletion in canine ovaries. The Society for the Study or Reproduction. 38 ${ }^{\text {th }}$ Annual Meeting, July 24-27, 2005, Quebec City, Quebec, Canada.

PAKSOY, Z. (2012): Administration of 4-vinyl-1-cyclohexene 1,2-epoxide diminishes ovarian follicles in dogs. Reprod. Domest. Anim. 47 (s4), 610-611.

PLACER, Z. A., L. L. CHUSMAN, B. C. JOHNSON (1966): Estimation of product of lipid peroxidation (malonyl dialdehyde) in biochemical systems. Anal. Biochem. 16, 359-364.

DOI: 10.1016/0003-2697(66)90167-9

SAHAMBI, S. K., J. A. VISSER, A. P. THEMMEN, L. P. MAYER, P. J. DEVINE (2008): Correlation of serum anti-Müllerian hormone with accelerated follicle loss following 4-vinylcyclohexene diepoxide-induced follicle loss in mice. Reprod. Toxicol. 26, 116-122.

DOI: 10.1016/j.reprotox.2008.07.005

SALHAB, A. S., M. S. SHOMAF, M. N. GHARAIBEH, N. A. AMER (1999): Effects of castor bean extract and ricin A-chain on ovulation and implantation in rabbits. Contraception 59, 395-399.

DOI: $10.1016 / \mathrm{S} 0010-7824(99) 00045-1$ 
SEDLAK, J., R. H. C. LINDSAY (1968): Estimation of total protein bound and nonprotein sulfhydryl groups in tissue with Ellmann's reagent. Anal. Biochem. 25, 192-205.

DOI: 10.1016/0003-2697(68)90092-4

SUN, Y., W. O. LARRY, L. YING (1988): A simple method for clinical assay of superoxide dismutase. Clin. Chem. 34, 497-500.

VAN KEMPEN, T. A., T. A. MILNER, E. M. WATERS (2011): Accelerated ovarian failure: a novel, chemically induced animal model of menopause. Brain Res. 1379, 176-187.

DOI: $10.1016 /$ j.brainres.2010.12.064

WIEBE, V. J., J. P. HOWARD (2009): Pharmacologic advances in canine and feline reproduction. Top. Companion Anim. Med. 24, 71-99.

DOI: $10.1053 /$ j.tcam.2008.12.004

YODER, C. A., L. A. MILLER (2010): Effect of GonaCon ${ }^{\mathrm{TM}}$ vaccine on black-tailed prairie dogs: immune response and health effects. Vaccine 29, 233-239.

DOI: $10.1016 /$ j.vaccine.2010.10.055

Received: 28 September 2017

Accepted: 19 October 2018

\section{PAKSOY, Z., F. M. KANDEMİ, N. GOKHAN, M. OZKARACA: Učinci 4-vinilcikloheksen diepoksida na testise pasa. Vet. arhiv 88, 807-822, 2018. \\ SAŽETAK}

Cilj ovoga istraživanja bio je ispitati učinak 4-vinilcikloheksen diepoksida (VCD) na tkivo testisa u pasa. U tu je svrhu 30 mužjaka, križanaca, slučajnim odabirom podijeljeno u pet skupina. Prvoj, kontrolnoj skupini (n =6) dan je VCD sa sezamovim uljem intraperitonealno. Druga skupina primila je VCD intraperitonealno u dozi od $80 \mathrm{mg} / \mathrm{kg}$, treća $160 \mathrm{mg} / \mathrm{kg}$, četvrta $240 \mathrm{mg} / \mathrm{kg}$ i peta skupina $320 \mathrm{mg} / \mathrm{kg}(\mathrm{n}=6)$, jedanput dnevno tijekom 8 dana. Psi su kastrirani dan nakon posljednje injekcije VCD-a. Testisi su odmah uklonjeni i stavljeni u $10 \%$-tni Bouineov fiksativ. Podvrgnuti su rutinskoj obradi tkiva te ispitani da se utvrde oštećenja na svakom testisu. U usporedbi s kontrolnom skupinom uočeno je da je u pokusnoj skupini oštećenje sjemenovoda značajno veće. Razine malondialdehida najveće su vrijednosti dosegnule u petoj skupini, dok je aktivnost superoksidne dismutaze, katalaze i glutation-peroksidaze bila veća u kontrolnoj skupini $(\mathrm{P}<0,0001)$. Aktivnosti AST-a, ALT-a i GGT-a nisu pokazale značajnu razliku među skupinama prije i poslije tretmana $(\mathrm{P}>0,05)$. Rezultati pokazuju da VCD može pridonijeti sterilitetu kod muških pasa.

Ključne riječi: 4-vinil-cikloheksen diepoksid; kemijska sterilizacija; pas; testis 